\title{
OSTEOBLASTS WITH IMPAIRED SPREADING CAPACITY BENEFIT FROM THE POSITIVE CHARGES OF PLASMA POLYMERISED ALLYLAMINE
}

\author{
F. Kunz ${ }^{1,2}$, H. Rebl ${ }^{1}$, A. Quade ${ }^{3}$, C. Matschegewski ${ }^{1,4}$, B. Finke ${ }^{3}$ and J. B. Nebe ${ }^{1, *}$ \\ ${ }^{1}$ University Medical Centre Rostock, Department of Cell Biology, Rostock, Germany \\ ${ }^{2}$ University of Rostock, Faculty of Interdisciplinary Research, Rostock, Germany \\ ${ }^{3}$ Leibniz Institute for Plasma Science and Technology e.V. (INP), Greifswald, Germany \\ ${ }^{4}$ University of Rostock, Faculty of Agricultural and Environmental Sciences, Rostock, Germany
}

\begin{abstract}
Bone diseases such as osteoporosis, osteoarthritis and rheumatoid arthritis, impinge on the performance of orthopaedic implants by impairing bone regeneration. For this reason, the development of effective surface modifications supporting the ingrowth of implants in morbid bone tissue is essential. Our study is designed to elucidate if cells with restricted cell-function limiting adhesion processes benefit from plasma polymer deposition on titanium. We used the actin filament disrupting agent cytochalasin $\mathrm{D}(\mathrm{CD})$ as an experimental model for cells with impaired actin cytoskeleton. Indeed, the cell's capacity to adhere and spread was drastically reduced due to shortened actin filaments and vinculin contacts that were smaller. The coating of titanium with a positively charged nanolayer of plasma polymerised allylamine (PPAAm) abrogated these disadvantages in cell adhesion and the CD-treated osteoblasts were able to spread significantly. Interestingly, PPAAm increased spreading by causing enhanced vinculin number and contact length, but without significantly reorganising actin filaments. PPAAm with the monomer allylamine was deposited in a microwave-excited low-pressure plasma-processing reactor. Cell physiology was monitored by flow cytometry and confocal laser scanning microscopy, and the length and number of actin filaments was quantified by mathematical image processing. We showed that biomaterial surface modification with PPAAm could be beneficial even for osteoblasts with impaired cytoskeleton components. These insights into in vitro conditions may be used for the evaluation of future strategies to design implants for morbid bone tissue.
\end{abstract}

Keywords: Osteoblast function, actin cytoskeleton, vinculin, spreading, cytochalasin $\mathrm{D}$, titanium, surface modification, plasma polymerised allylamine, surface charge.

\footnotetext{
*Address for correspondence:

Prof. Dr. J. Barbara Nebe

University Medical Centre Rostock

Department of Cell Biology

Schillingallee 69

18057 Rostock, Germany
}

Telephone Number: +493814947771

FAX Number: +49 3814947764

E-mail: barbara.nebe@med.uni-rostock.de

\section{Introduction}

For a successful osseointegration and long-term stability of load-bearing bone implants, sufficient initial cellular occupation of implant surfaces by osteoblasts is essential. Cellular colonisation of implant surfaces requires the cell's ability to adhere, spread, grow, proliferate and differentiate on the bone substitute material. In bone, the balance between bone matrix synthesising osteoblast and bone resorbing osteoclast activity can be influenced by local and systemic factors, in physiological as well as in pathological conditions, leading to bone remodelling imbalanced towards increased bone resorption (Neve et al., 2011). Osteoblasts play a crucial role in controlling bone remodelling (Beil et al., 2008; Corrado et al., 2005; Dequeker et al., 1993; El Miedany et al., 2000; Hilal et al., 1998; Lajeunesse and Reboul, 2003; Perrini et al., 2008; Walsh et al., 2009).

Reduced osteoblast proliferation and bone matrix secretion, where osteoclastic activity is maintained, will lead to net bone loss. Local factors including cytokines, prostaglandins, leukotrienes, nitric oxide and growth factors, which are produced locally by bone cells, influence the osteoblast-osteoclast interplay (Raisz and Prestwood, 2000). Bone loss caused by exposure to microgravity has been observed in astronauts (Klein-Nulend et al., 2003). A space flight study of Nabavi et al. (2011) revealed that osteoblasts exposed to microgravity had smaller and fewer focal adhesions, thinner cortical actin and stress fibres as well as extended cell shapes. The morphology changed and number of focal adhesion proteins vinculin, paxillin and zyxin were reduced, in the absence of external gravity forces. These findings impressively demonstrate that impaired adhesion components can be linked to bone loss. Further, in vivo and in vitro investigations (Nileback et al., 2014) underline the importance of the cytoskeleton in osteoblast and osteoclast function.

In modern orthopaedic surgery, there are many implant materials for the permanent reconstruction of injured bone. However, these implants are not adapted for use in systemically diseased bone with, for example, reduced trabecular thickness and density as well as impaired osteoblast activity. Since the success of orthopaedic implants depends on the cellular acceptance and occupation of implant surfaces by cells from the surrounding bone tissue, pathological conditions can lead to insufficient cellular occupancy of implants, inferior osseointegration, post-operative complications and implant loosening.

To improve the performance of bone implants in pathologically altered bone tissue, the challenge is to 
design material surfaces that specifically support the impaired osteoblasts in executing their first colonising steps. The initial contact at the cell-biomaterial interface and subsequent cell adhesion and spreading are critical for adequate osteoblast cell function and bone matrix secretion. The molecules responsible for these processes involve adhesion receptors, such as the heterodimeric transmembrane integrins, the actin cytoskeleton, and the cytoskeletally associated proteins, such as vinculin, paxillin and talin (Ezzell et al., 1997; Ruoslahti and Öbrink, 1996). In this interplay, the actin cytoskeleton is decisive; it serves not only as a scaffold for adaptor proteins and intracellular signalling molecules (Brakebusch and Fässler, 2003) but is also responsible for cell migration, formation of the cell's lamellipodia and the dynamically regulated overall cell shape important for specific cell functions (Sun et al., 2012)

Therefore, the development of bioactive surfaces that stimulate early cell adhesion of impaired cells, for example with restricted adhesion components, would be beneficial for the outcome of implant stability. For this purpose, we used the F-actin disrupting agent cytochalasin D (Parreno et al., 2008) to artificially impair the adhesion-related cell functions. Recently, we recognised that titanium (Ti) surfaces functionalised with plasma-polymerised allylamine (PPAAm) have a strong promoting effect on physiologically normal cells in respect to morphology and cell attachment (Finke et al., 2007; Rebl et al., 2012; Rebl et al., 2010). Furthermore, our new results in vivo confirmed these findings - the bone-to-implant contact zone (histomorphometry) in the medial tibia of rats was decisively increased after six weeks if the titanium alloy (Ti6A14V) implant was covered with PPAAm or an ethylenediamine (Gabler et al., 2014). The deposited plasma-polymerised nanofilm presents amino groups that are positively charged in aqueous solutions at physiological $\mathrm{pH}$-values and covers the negatively charged, naturally oxidised Ti surface (Hoene et al., 2010).

These beneficial PPAAm effects may be linked to an influence on protein adsorption. Protein adsorption on surfaces, being the first event of the biological response to materials, occurs immediately when the surface is immersed in aqueous solutions (Vogler, 2012). In vivo, implant surfaces come into contact with interstitial fluid, blood or other body fluids containing a multiplicity of growth factors, cytokines, hormones and other constituents. Since cells interact with these adsorbed molecules and not with the underlying material surface, the properties of the protein layer influence cellular behaviour and control biocompatibility (Ratner and Bryant, 2004). Allylamine plasma polymer seems to feature high adsorptivity, as has been exemplarily demonstrated for the enzyme trypsin (Abbas et al., 2009). This could link the polyelectrolyte properties of PPAAm with a higher adsorption of biomolecules from medium and serum components (such as fibronectin) that in turn favour cell adhesion by means of integrin-mediated focal adhesion complexes.

Here, we wished to shed light on the question of whether the plasma polymer nanolayer PPAAm is effective in supporting physiologically restricted osteoblasts, and whether it would be able to promote osteoblastic anchorage even in unfavourable preconditions. We focussed on the examination of cell adhesion, spreading, organisation and quantification of actin filaments, as well as the formation of the focal adhesion-related protein vinculin.

\section{Materials and Methods}

\section{Titanium discs}

Ti disks of technical purity (cp, grade 2; ThyssenKrupp, Essen, Germany), $11 \mathrm{~mm}$ in diameter and $1 \mathrm{~mm}$ in height with a mechanically polished surface on the upper side (graining 4,000, $\left.\mathrm{R}_{\mathrm{a}}=0.05 \mu \mathrm{m}\right)(\mathrm{Rebl}$ et al., 2012) were obtained from DÖT GmbH (Rostock, Germany) and used for the chemical functionalisation, or as reference specimens.

\section{Functionalisation of titanium with plasma polymer}

Functionalisation of $\mathrm{Ti}$ with the plasma-polymerised allylamine $\left(\mathrm{H}_{2} \mathrm{C}=\mathrm{CH}-\mathrm{H}_{2} \mathrm{C}-\mathrm{NH}_{2}, \mathrm{C}_{3} \mathrm{H}_{7} \mathrm{~N}\right)$ (sample name: TiPPAAm) was performed as described earlier by (Finke et al., 2007) in a low-pressure plasma-processing reactor V55G (Plasma-finish GmbH, Schwedt, Germany, V: 60 L) in a two-step procedure. First, the Ti specimens were decontaminated and activated by a continuous-wave (cw) oxygen plasma $(500 \mathrm{~W}, 50 \mathrm{~Pa}, 100 \mathrm{sccm} \mathrm{O}, 25 \mathrm{sccm}$ $\mathrm{Ar})$. Then, the plasma polymerisation of the monomer allylamine was realised using a microwave-excited $(2.45 \mathrm{GHz}, 500 \mathrm{~W})$, pulsed (duty cycle of 0.15 at a pulse length of $2 \mathrm{~s})$, low pressure (50 Pa) gas-discharge plasma for an effective treatment duration of $144 \mathrm{~s}$ (PPAAm) (Finke et al., 2007). A liquid-handling system allows an exact dosing of allylamine. Prior to use, the allylamine was carefully purified of air by evacuating and purging with $\mathrm{N}_{2}$. Argon was applied as a carrier gas $(50 \mathrm{sccm}$ Ar). The substrate was located in a downstream plasma position. After this PPAAm deposition procedure, the functionalised Ti specimen is sterile by nature of the process. All specimens were taken directly from the reactor using aseptic techniques and put into sterile packages. In general, the PPAAm nanolayer is $\gamma$-sterilisable (Nebe et al., 2013) and long-term stable in its adhesive characteristics (>180 d) (Finke et al., 2014; Finke et al., 2011b).

The TiPPAAm nanolayer was verified by atomic force microscopy (AFM), X-ray photoelectron spectroscopy (XPS), water contact angle (sessile drop method) and zeta potential measurement, as described and analysed earlier (Finke et al., 2007). Briefly, the well cross-linked, mechanically stable PPAAm nanolayer resistant to hydrolysis and insoluble in water features the following characteristics: thickness about $50 \mathrm{~nm}$ (see Rebl et al., 2010), water contact angle TiPPAAm $48^{\circ} v s$. pure Ti $78^{\circ}$ (due to the contamination of the native oxide layer by hydrocarbons in the ambient air), and zeta potential at pH 6.0: TiPPAAm +7.7 mV vs. pure Ti -3.4 mV (for both see Finke et al., 2007). Complementary elemental analysis using XPS showed a closed, pinhole-free polymer film with an N/C ratio between 25 and $30 \%$ (see Nebe et al., 2007a) but without any Ti signal. 


\section{Cell culture}

Human MG-63 osteoblastic cells (cell line, ATCC, Manassas, VA, USA/LGC Promochem, Wesel, Germany) were cultured in Dulbecco's modified Eagle's medium (DMEM; Gibco/Invitrogen, Carlsbad, CA, USA) with $10 \%$ foetal calf serum Gold (PAA Laboratories, Cölbe, Germany), $1 \%$ gentamicin (Ratiopharm, Ulm, Germany) at $37^{\circ} \mathrm{C}$, in a humidified $5 \% \mathrm{CO}_{2}$ atmosphere. The medium was changed every other day.

For cell counting, the cells were enzymatically detached by immersing them for $5 \mathrm{~min}$ in $0.05 \%$ trypsin $/ 0.02 \%$ ethylene diamine tetraacetic acid (EDTA; PAA Laboratories, Cölbe, Germany). After stopping trypsinisation with complete cell culture medium, three aliquots of $100 \mu \mathrm{L}$ each were put into $10 \mathrm{~mL}$ of CASY ${ }^{\circledR}$ ton buffer solution (Innovatis, Bielefeld, Germany) and measured in the cell counter CASY ${ }^{\circledR}$ Model DT (Schärfe System, Reutlingen, Germany).

\section{Cytochalasin D}

Artificial disruption of the actin cytoskeleton was induced by seeding and subsequent incubation of cells in standard culture medium (see above) with $1 \mu \mathrm{M}$ cytochalasin $\mathrm{D}$ (CD) (Sigma-Aldrich, St. Louis MO, USA; stock solution in phosphate-buffered saline, PBS, final dilution in medium). This fungus-derived and actin-disrupting agent leads to the disassembly of actin filaments by a perturbation of the filament turnover (Hagiwara et al., 2011), especially by binding to the barbed (plus) end of growing actin filaments, inhibiting polymerisation (Bray, 1992).

Prior to these experiments, the cytotoxicity of $\mathrm{CD}$ was assessed by photometric measurement of the cell viability using the CellTiter $96^{\circledR}$ AQueous One Solution Cell Proliferation Assay (Promega, Madison WI, USA, Cat. No. G3580/1). Briefly, MG-63 cells $\left(3 \times 10^{4} / 0.5 \mathrm{~mL}\right)$ were cultured in 48 -well plates (Greiner Bio-One, Frickenhausen, Germany) for 1, 2 and $7 \mathrm{~d}$, in the absence (control) or presence of CD $(0.1,1$ and $10 \mu \mathrm{M})$. After cell culture, the medium was replaced by fresh medium supplemented with dimethylthiazol carboxy-methoxyphenyl sulfophenyl tetrazolium (MTS) test solution according to the manufacturer's protocol, and cells were incubated for $3 \mathrm{~h}$ at $37{ }^{\circ} \mathrm{C}$. During the incubation time, the plates were gently pivoted several times. From each well $3 \times 100 \mu \mathrm{L}$ were transferred into 3 empty wells (100 $\mu \mathrm{L} /$ well) of 96 -well plates (Greiner Bio-One). Photometric measurement of absorption was performed using an Anthos 2010 microplate reader (Anthos Microsysteme, Krefeld, Germany) at $490 \mathrm{~nm}$. A viability of higher than or equal to $80 \%$ of the untreated control was considered acceptable for the further experimental use of the tested CD concentration (data not shown). Following these criteria, the test concentration of $1 \mu \mathrm{M} C D$ was categorised to be non-toxic within the experimental time frame of $48 \mathrm{~h}$.

\section{Cell membrane staining for the spreading analysis}

To make the cells visible for microscopic investigations on the opaque titanium, osteoblasts were labelled with the fluorescent dye PKH26 for vital cells (PKH26 Red Fluorescent Cell Linker Kit for General Cell Membrane Labelling, Sigma-Aldrich) before seeding on the Ti discs (Nebe et al., 2007b). This fluorescent dye did not influence the cell growth of cultured osteoblasts - the cell cycle phases S (synthesis) and G2/M (gap2/mitosis) of PKH26stained cells measured by flow cytometry were comparable to unstained cells (88.85 vs. $86.62 \%$, respectively), as was the total RNA (isolated using Nucleo-Spin RNA kit, Macherey-Nagel, Düren, Germany) after $7 \mathrm{~d}$ of cell culture (13.55 vs. $12.37 \mu \mathrm{g}$, respectively). The sensitivity of the PKH26-stained cells to topographical and chemical features of material surfaces was maintained as described (Finke et al., 2007; Lüthen et al., 2005; Nebe et al., 2007b). The PKH26 staining procedure is as follows: cultured MG63 osteoblasts (see above) were trypsinised and washed in PBS. The cell membranes of $1 \times 10^{6}$ suspended cells (in $250 \mu \mathrm{L}$ of diluent $\mathrm{C}$ according to the kit instructions) were then stained with the red fluorescent linker PKH26 for $5 \mathrm{~min}$ at $37^{\circ} \mathrm{C}$ using a dilution of $2 \mu \mathrm{L}$ of PKH2 6 and $248 \mu \mathrm{L}$ of diluent $\mathrm{C}$.

The membrane-stained cells were then seeded onto the Ti discs and cultured for $3 \mathrm{~h}$ in DMEM as described above. After this culture time, cells were rinsed in PBS and fixed with $4 \%$ paraformaldehyde (PFA; Merck, Darmstadt, Germany) for $10 \mathrm{~min}$ at room temperature (RT). The cells on the Ti were embedded with a coverslip using Fluoroshield ${ }^{\mathrm{TM}}$ mounting medium (Sigma-Aldrich, Art. No. F6182).

Cells were examined microscopically (LSM 410, Carl Zeiss, Oberkochen, Germany), and the spreading (cell area in $\mu \mathrm{m}^{2}$ ) of 40 cells per specimen was then analysed using the software function "area measurement" of the confocal microscope.

\section{Flow cytometric measurement of cell adhesion}

Suspended MG-63 cells in DMEM with $10 \%$ FCS $\left(5 \times 10^{4}\right.$ cells $/ 0.3 \mathrm{~mL}$ ) were seeded onto Ti disks (Fig. 1) in medium either without $\mathrm{CD}$ (control) or with $1 \mu \mathrm{M} \mathrm{CD}$. To avoid the

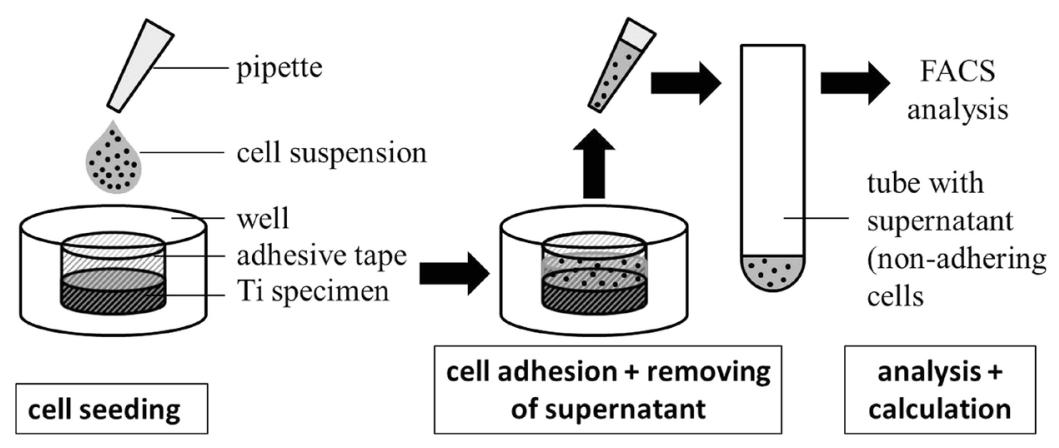

Fig. 1. Method illustration for analysis of cell adhesion. 
seeding of cells beside the Ti, samples were laterally fixed in adhesive tapes (Carl Roth, Karlsruhe, Germany). After 10 min to allow cell sedimentation and adhesion to the Ti disk surface, the supernatant containing the non-adherent cells (i.e. cells that did not adhere to the surface within the given period of time) was then drawn up with a pipette, transferred into $12 \times 75 \mathrm{~mm}$ test tubes and analysed by flow cytometry (FACSCalibur ${ }^{\mathrm{TM}}$; BD Biosciences, Heidelberg, Germany). Cell adhesion of $n=5$ independent experiments was then calculated in percent.

\section{Actin cytoskeleton}

MG-63 cells $\left(1.5 \times 10^{4} / 0.5 \mathrm{~mL}\right.$ corresponding to approx. $\left.1.6 \times 10^{4} / \mathrm{cm}^{2}\right)$ were cultured on the Ti discs for $24 \mathrm{~h}$ in the absence (control) or presence of CD $(1 \mu \mathrm{M})$. Then, cells were fixed with $4 \%$ PFA for $10 \mathrm{~min}$ at RT. After washing with PBS, cells were permeabilised with $0.1 \%$ Triton $^{\mathbb{B}}$ X-100 (Merck; $10 \mathrm{~min}, \mathrm{RT}$ ), incubated with phallacidin BODIPY FL (diluted 1:100, Molecular Probes, Eugene, OR, USA) for $30 \mathrm{~min}$ in the dark at RT, washed again, embedded as described above and examined on the confocal microscope.

\section{Vinculin formation}

After culturing MG-63 cells $\left(1.6 \times 10^{4} / \mathrm{cm}^{2}\right)$ on Ti samples for $24 \mathrm{~h}$ in the absence (control) or presence of CD $(1 \mu \mathrm{M})$, the samples were washed twice with PBS, fixed by $4 \%$ PFA for $10 \mathrm{~min}$ at RT and then permeated with $0.1 \%$ Triton X-100 for $10 \mathrm{~min}$ at RT, followed by two rinses with PBS. Vinculin was first recognised by anti-vinculin mouse monoclonal antibody (Sigma-Aldrich; diluted 1:100 in PBS) for $60 \mathrm{~min}$ at RT, followed by labelling with rabbit anti-mouse Cy-3 antibody (Dianova, Hamburg, Germany; diluted 1:200 in PBS) for $30 \mathrm{~min}$ at RT in the dark. After washing twice with PBS and once with distilled water, the specimens were embedded and stored at $4{ }^{\circ} \mathrm{C}$ in the dark until microscopic observation. The length of the vinculin contacts was measured using the LSM 410 software function "measurement".

\section{Confocal microscopy}

Microscopic examinations were performed on an inverted LSM 410 confocal laser scanning microscope (Carl Zeiss) equipped with an argon-ion laser (excitation $488 \mathrm{~nm}$ for phallacidin BODIPY FL) and an HeNe laser (excitation $543 \mathrm{~nm}$ for PKH-26 and Cy-3 antibody) as well as a $63 \times$ water objective $(1.25 / 0.17$, Carl Zeiss). The size of the images was $512 \times 512$ pixels.

\section{Quantification of actin filaments using mathematical image processing}

For an objective and quantitative analysis of the cellular actin filament distribution, the newly developed software entitled FilaQuant, specified as a Win32 application with Embarcadero $^{\circledR}$ C++Builder ${ }^{\circledR} 2010$ (University of Rostock, Institute of Mathematics, Mathematical Optimisation) was used (Birkholz, 2011a). The microscopic images were processed in three steps according to (Matschegewski et al., 2012): pre-processing, feature detection and quantification. Before feature detection, the main sources of errors were reduced, namely noise, by variational methods (Birkholz, 2011b) and irregular background illumination by morphological white top-hat (Gonzalez and Woods, 2008). Details of this method and an evaluation of measurement errors in the use for quantification can be found in (Birkholz, 2011a). For the quantification of the actin cytoskeleton concerning its average length and number of filaments, 10 representative osteoblastic cells per specimen of 3 independent experiments were analysed with FilaQuant to reduce the pre-analytical settings of the FilaQuant software.

\section{Statistics}

Statistical analyses of the data sets were performed using the software SPSS 20.0 for Windows (SPSS Inc., Chicago, IL, USA). Data are expressed as boxplots with boxes indicating median and interquartile range and whiskers minimum and maximum values. Statistical significance is obtained from a Mann-Whitney U test or one-way ANOVA. The $p$ values less than 0.05 were considered statistically significant $\left({ }^{\mathrm{a}} p<0.05,{ }^{\mathrm{b}} p<0.01,{ }^{\mathrm{c}} p<0.001\right)$.

\section{Results}

\section{Cell adhesion}

Assessment of short time (10 min) cell adhesion by flow cytometry (Fig. 2) revealed that plasma polymer coating with PPAAm strongly increased cell adhesion compared to the Ti control surface ( $68 \pm 6 \%$ vs. $45 \pm 7 \%$, respectively). $\mathrm{CD}$ treatment reduced the number of adherent cells on PPAAm (TiPPAAm+CD) slightly but not significantly, as well as on $\mathrm{Ti}(\mathrm{Ti}+\mathrm{CD})$ with $56 \pm 11 \%$ and $37 \pm 10 \%$, respectively.

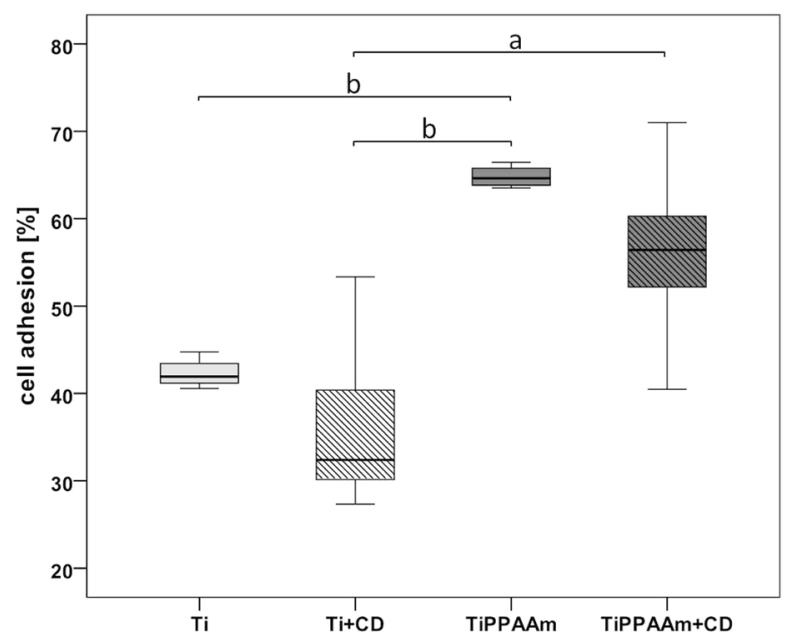

Fig. 2. MG-63 cell adhesion (10 min) after seeding onto PPAAm-modified Ti in the absence or presence of $1 \mu \mathrm{M}$ cytochalasin D (CD). Note that PPAAm enhances cell adhesion dramatically, whereas the actin-disrupting agent $\mathrm{CD}$ has no influence, demonstrating that the actin filaments seem not to be involved in initial cell adhesion. (Flow cytometry, $n=5$ independent experiments, MannWhitney-U-test, $\left.{ }^{\mathrm{a}} p<0.05,{ }^{\mathrm{b}} p<0.01\right)$. 


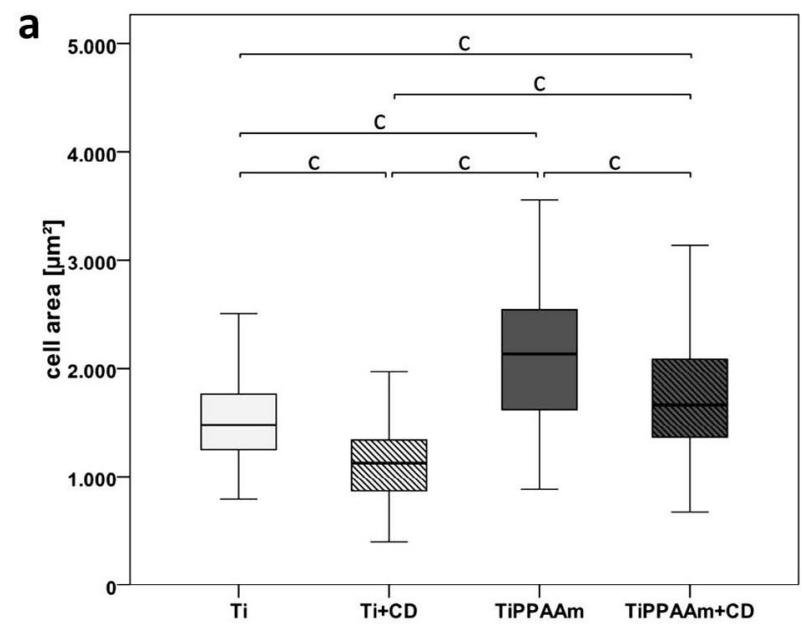

b
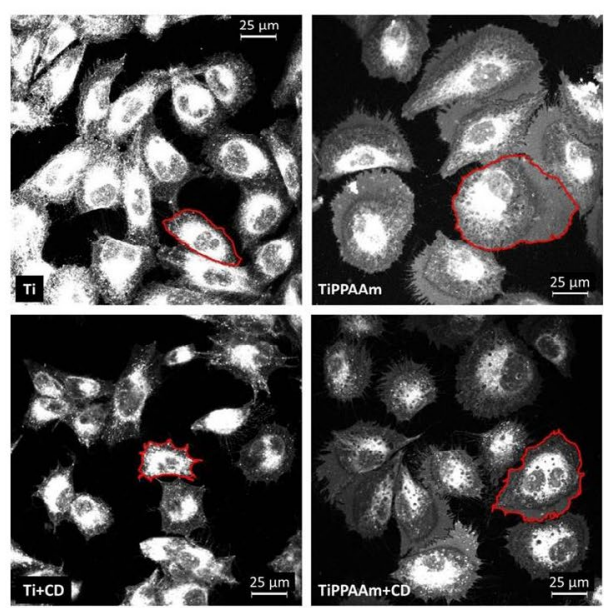

Fig. 3. Cell spreading of MG-63 cells after $3 \mathrm{~h}$ on PPAAm-modified Ti in the absence or presence of $1 \mu \mathrm{M}$ CD. Note the significant increase of cell area (a) evoked by PPAAm and that the significant decline caused by CD can be overcome by PPAAm. The red line (examples) in the microscopic images (b) indicates the cell area (in $\mu \mathrm{m}^{2}$ ) measured by the software "area measurement" of the confocal microscope (LSM 410). ( $n=4$ independent experiments at 40 cells each, Mann-Whitney U-test, $\left.{ }^{\mathrm{c}} p<0.001\right)$.

\section{Cell spreading}

Cell spreading analysis (Fig. 3) revealed a significant supporting effect of PPAAm compared to control cells $\left(2.176 \mu \mathrm{m}^{2} v s .1 .510 \mu \mathrm{m}^{2}\right.$, respectively) after $3 \mathrm{~h}$, amounting to $144 \%$ of the control. In osteoblasts physiologically restricted due to $\mathrm{CD}(\mathrm{Ti}+\mathrm{CD})$, a distinct reduction of cell area $\left(1.139 \mu \mathrm{m}^{2}\right)$ was observed - a decline to $75 \%$ of the control. On the plasma polymer layer in the presence of CD (TiPPAAm+CD), the mean cell area $\left(1.836 \mu \mathrm{m}^{2}\right)$ still reached $122 \%$ of the Ti control. PPAAm was able not only to compensate but even to overcompensate the negative effect of this F-actin disrupting agent.

\section{Organisation of filamentous actin}

MG-63 osteoblasts cultured for $24 \mathrm{~h}$ on Ti and TiPPAAm form strong actin filament bundles in addition to long peripheral stress fibres (Figs. 4a,b). CD treatment results in an almost complete loss of actin filament bundles whereas peripheral actin filaments are still partially maintained (Fig. 4c). CD-treated cells on TiPPAAm also demonstrate a fragmented F-actin cytoskeleton, but show some additional subtle actin bundles (Fig. 4d) and a slight reorganisation of actin.

Actin quantification by the FilaQuant software is visualised (Fig. 5) by the filament graphs corresponding to the original confocal microscopic images (insets in Fig. 5a-d). FilaQuant defines each filament by a distinct colour, here converted to grayscale. The characteristic features of the linear actin filament structures exhibited by the cells are maintained during the mathematical procedure.

The mean number of actin filaments per cell is influenced by $\mathrm{CD}$ due to its mechanism of action in disrupting existing filaments as well as by the material surface chemistry (Fig. 6). On Ti, normal cells possessed 41 filaments/cell, whereas after CD treatment, the mean filament number increased to 58/cell. No difference was detected between Ti control and plasma polymer coated Ti. For cells on TiPPAAm and TiPPAAm $+\mathrm{CD}$, a mean of 43 and 36 filaments/cell was observed, respectively. Interestingly, cells grown on the plasma polymer can partially overcome the influence of CD (sample TiPPAAm+CD) and reorganise their actin filaments in fibres, and therefore the number of actin filaments has the tendency to approximate the number of TiPPAAm and the control Ti.

The mean filament length (Fig. 7) is highest on Ti $(14 \mu \mathrm{m})$ and PPAAm $(11 \mu \mathrm{m})$. CD significantly reduced the mean filament length of cells on both $\mathrm{Ti}+\mathrm{CD}(5 \mu \mathrm{m})$ and PPAAm + CD $(6 \mu \mathrm{m})$. This represents a reduction of more than $50 \%$ of the Ti control, independent of the presence or absence of PPAAm coating. Comparing the mean length values of TiPPAAm $+\mathrm{CD}$ with their corresponding confocal images in Fig. 4, it seems that the FilaQuant software could not convert the image very well due to the slim actin fibres that were newly organised.

\section{Vinculin contact formation}

CD-treated cells on Ti exhibited slightly, but not significantly, more vinculin contacts than untreated cells on Ti (mean, 25 versus 19 contacts/cell, respectively) (Fig. $8)$. In contrast, the number of vinculin contacts in untreated cells on PPAAm increased to 55 contacts/cell, this being only non-significantly reduced to 48 contacts/cell by CD.

Cells treated with $\mathrm{CD}$ exhibit a shortened vinculin contact phenotype on Ti compared to untreated osteoblasts on Ti (Figs. 9b,c). The mean length of vinculin contacts (Fig. 9a) is diminished by CD by about half, from $3.4 \mu \mathrm{m}$ to $1.8 \mu \mathrm{m}$ for Ti $v s$. Ti $+\mathrm{CD}$, respectively. For PPAAm, this negative $C D$ effect was less pronounced, but significant with $3.3 \mu \mathrm{m}$ for TiPPAAm and $2.6 \mu \mathrm{m}$ for TiPPAAm $+\mathrm{CD}$. The compensatory effect of the plasma polymer layer on the formation of focal adhesions is obvious: cells physiologically restricted due to $\mathrm{CD}(\mathrm{Ti}+\mathrm{CD})$ are able to form longer vinculin contacts if supported by a PPAAm nanolayer (TiPPAAm $+\mathrm{CD}$ ) with a mean of $1.8 \mu \mathrm{m} v \mathrm{~s}$. $2.6 \mu \mathrm{m}$, respectively. 

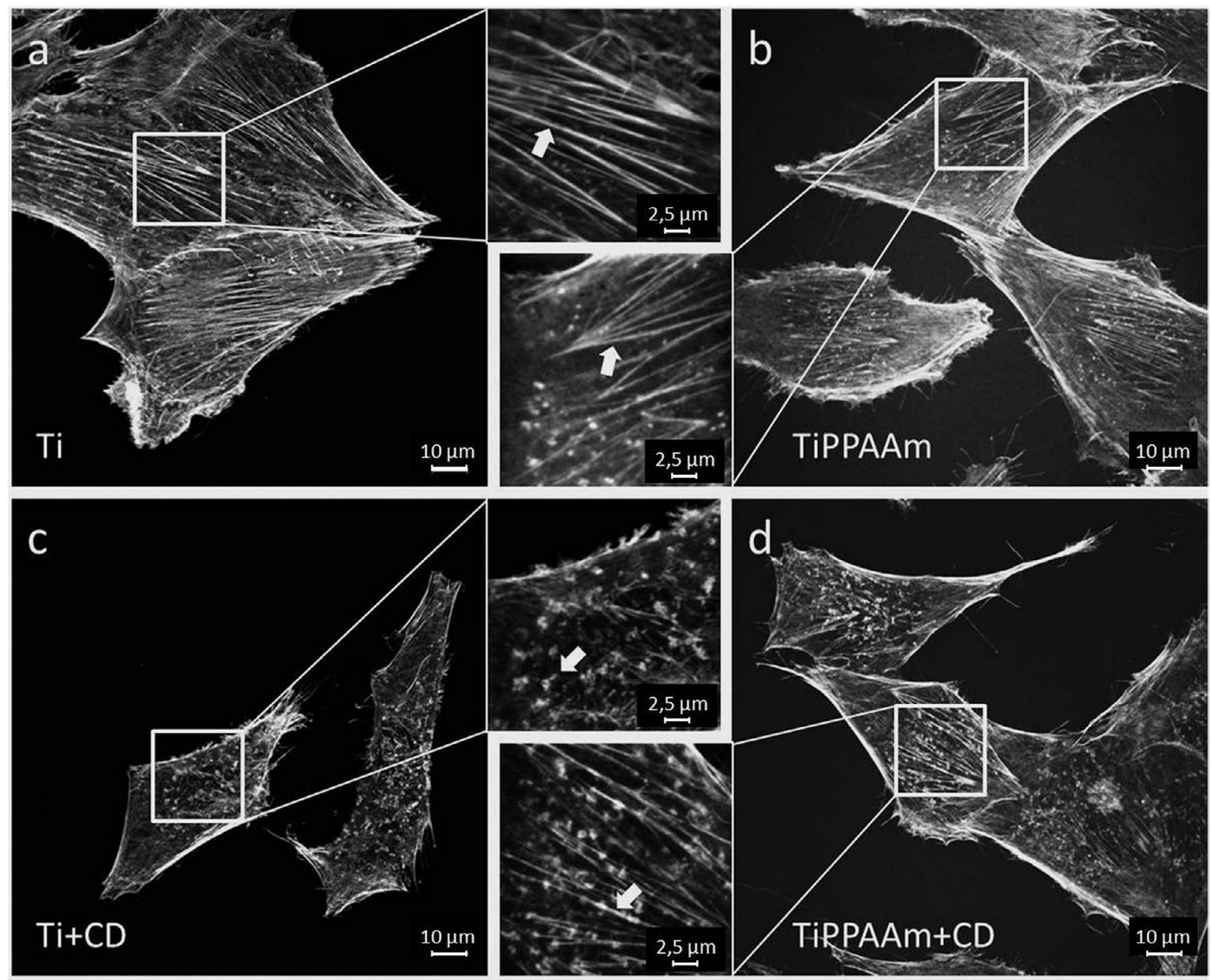

Fig. 4. Actin cytoskeleton in MG-63 cells after $24 \mathrm{~h}$ on PPAAm-modified Ti in the absence or presence of CD. Note that cells on $\mathrm{Ti}$ (a) are well spread with numerous, pronounced actin stress fibres (inset arrow). Actin filaments of cells on TiPPAAm (b) appear to be slimmer (inset arrow). CD treatment of cells on Ti (c) results in cluster-like, shortened actin fragments (inset arrow) throughout the retracted cell body. In contrast, CD-treated cells on TiPPAAm (d) maintain their morphology and actin filaments are reorganised and visible (inset arrow). The zoom insets indicate the characteristic organisation type of filamentous actin for each sample. (Confocal microscopy, overview: bar $=10 \mu \mathrm{m}$; Zoom: bar $=2.5 \mu \mathrm{m}$; LSM 410).

\section{Discussion}

In this in vitro study, our focus was to elucidate whether osteoblasts with experimentally impaired cell physiology due to F-actin disruption could be improved in their adhesion and spreading capacity on titanium surfaces by a plasma polymer nanolayer using allylamine.

To approximate the cell conditions that impair cellular adhesion in an in vitro cell culture approach, we chose the actin-disrupting drug cytochalasin D (CD). This cellpermeable agent is known to inhibit actin polymerisation by binding to G-actin and preventing polymerisation of actin monomers (May et al., 1998). Because it has this effect, CD is widely used to study actin cytoskeleton dependent processes in various cell types including osteoblasts (Myers et al., 2007; Parreno et al., 2008). Prior to the core experiments, the selected test concentration of $1 \mu \mathrm{M}$ CD was revealed not to be critical for cell metabolism within the investigated time frame of $48 \mathrm{~h}$, as described in the method section for cytochalasin. Also, cell-growth characteristics were not critically hampered with an equal number of cells in the apoptotic peak of the DNA histogram (data not shown). Therefore, the CD model artificially impairing cells allowed the monitoring of cellular processes within this period of time. Taking into account the advantages, disadvantages and limitations of in vitro cell models in biomedical research, the human osteoblast cell line MG-63 was chosen to study short term cell-material interactions, because MG-63 cells and primary human osteoblasts show similar integrin subunit profiles (Clover et al., 1992) as well as similarities in the formation of $\beta 1$ - and $\beta 3$-integrin adhesions grown on corundum blasted titanium (Lüthen et al., 2005). Moreover, MG-63 responds to hormonal administration in a way similar to primary human osteoblasts (Clover and Gowen, 1994; Lajeunesse et al., 1990). Therefore, this cell line has 

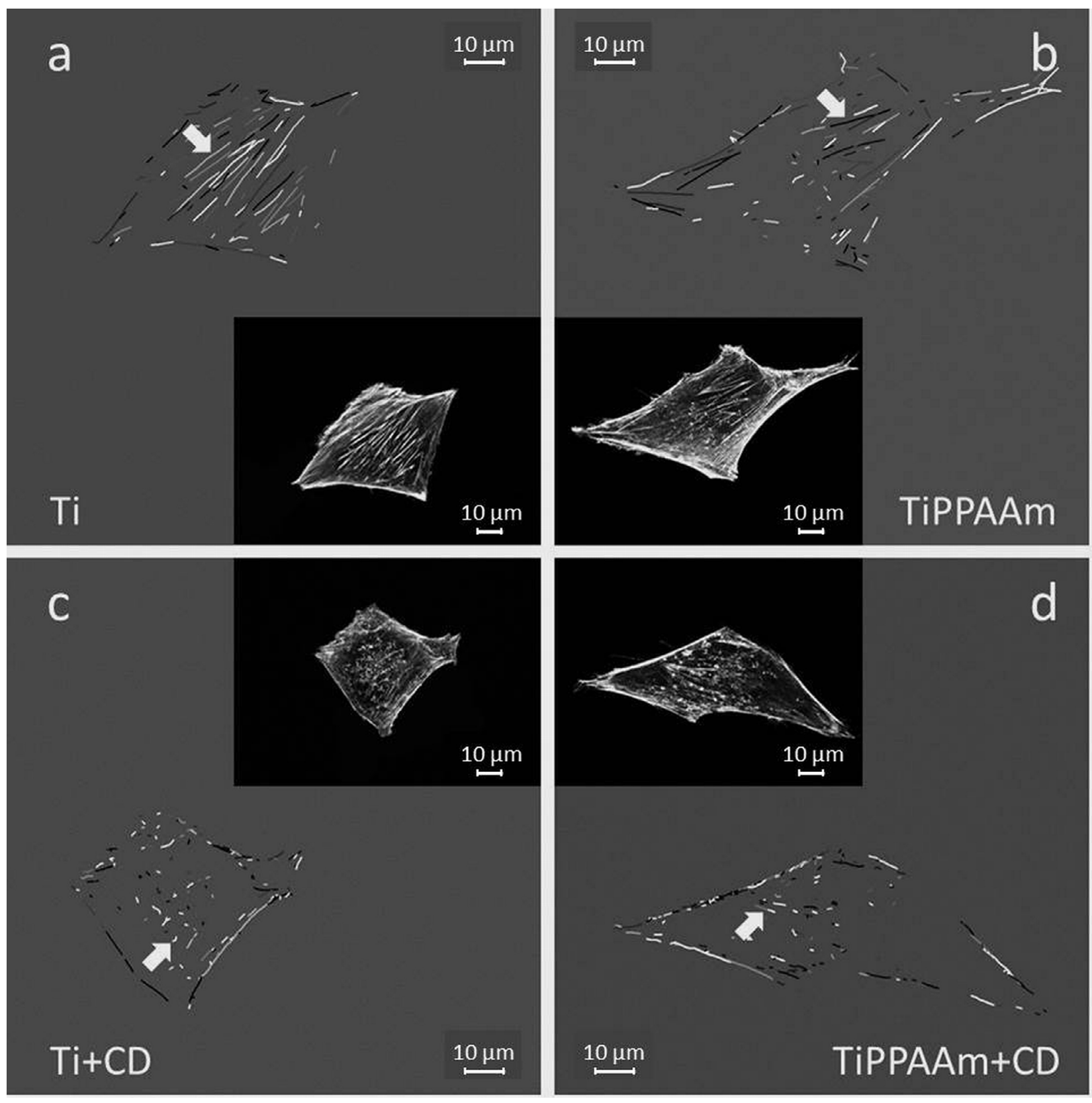

Fig. 5. FilaQuant filament curve graphs of actin filaments obtained from confocal microscopic images of MG-63 cells as a precondition for actin quantification (bars $=10 \mu \mathrm{m}$; LSM 410). Note the arrow-marked long central actin filaments on pure Ti (a) and PPAAm (b) in contrast to the short fragments in cells treated with cytochalasin D (c). Cells on PPAAm treated with CD (d) exhibit a few central thin filaments.

been considered applicable for investigating the initial cell attachment to biomaterials. To avoid individual and sourcedependent influences on cellular response, we considered a cell line more advantageous than primary human osteoblastic cells. However, as MG-63 is characterised by an immature osteoblast phenotype with low mineralisation capacity and because it underlies developmental changes in long-term culture, this cell type would be less favourable for long-term and mineralisation studies, as discussed in the excellent reviews by Czekanska et al. (2012) and Kartsogiannis and $\mathrm{Ng}$ (2004).

The experimental time span comprised the first $24 \mathrm{~h}$ after cell seeding, in which the cells perform attachment, adhesion and spreading on given surfaces. As we wanted to explore the importance of different preconditions (with CD/ without $\mathrm{CD}$ ) and different surfaces (Ti/ PPAAm) on cellular behaviour during these early events that are critical for subsequent cell growth, proliferation and differentiation, and finally, for the occupation of an implant material, we focussed on the time span usually needed for completing the spreading process and restricted the observation period to $24 \mathrm{~h}$.

Coating of the Ti surface with PPAAm strongly enhanced cell adhesion (10 min) and cell spreading (3 h). These control results are in accordance with previous in vitro studies on Ti (Finke et al., 2011a; Finke et al., 2007; Nebe et al., 2007a; Rebl et al., 2012; Rebl et al., 2010) and other materials, such as electrospun polylactide non- 


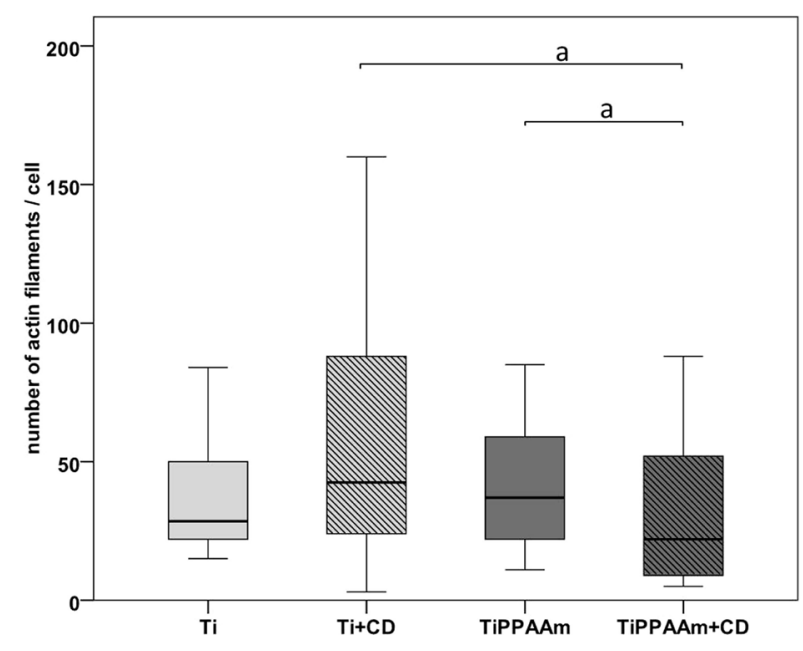

Fig. 6. Number of actin filaments in MG-63 cells after $24 \mathrm{~h}$ on PPAAm-modified Ti in the absence or presence of CD. (FilaQuant analysis of confocal microscopic images, $n=10$ cells/specimen, Mann-Whitney U-test, $\left.{ }^{\mathrm{a}} p<0.05\right)$.

wovens (Schnabelrauch et al., 2014; Wyrwa et al., 2011) or calcium phosphate scaffolds (Nebe et al., 2012). However, this cell adhesive effect of PPAAm is not restricted to osteoblasts, as it also could be confirmed for platelets, HUVEC, fibroblasts (Hamerli et al., 2003; Intranuovo et al., 2011; Yang et al., 2012; Yang et al., 2011), human gingiva epithelial and uroepithelial cells (Schnabelrauch et al., 2014) as well as human stem cells in vitro (Hamerli et al., 2003; Intranuovo et al., 2011; Schröder et al., 2010; Yang et al., 2012; Yang et al., 2011). As expected, CD caused a significant decline in cell area, which underlines the importance of an intact actin cytoskeleton for changes in cell shape during the spreading process. The dynamically organised actin cytoskeleton provides the force for cell spreading and motility and is regulated by small GTPases of the Rho family, in particular Rac1 (regulates lamellipodial protrusion), RhoA (controls stress fibre formation) and CDC42 (formation of filopodia) (Wittmann and Waterman-Storer, 2001). Remarkably, PPAAm-promoted cell spreading is, even in the presence of CD, on a higher level than the Ti control, showing for the first time the potential of this surface plasma modification to support also human cells with impaired cell functions.

Using confocal microscopy, the suppressed assembly of actin filaments and stress fibres following CD treatment could be clearly demonstrated in contrast to normal cell morphology on $\mathrm{Ti}$, which is dominated by prominent actin stress fibres. The more filigree appearance of the actin cytoskeleton on PPAAm can be speculatively explained by the reduced stiffness of the PPAAm layer compared to $\mathrm{Ti}$, as substrate elasticity is sensed by adherent cells, thus influencing the organisation of actin cytoskeleton (Walcott and Sun, 2010; Yeung et al., 2005). In their mechanistic model, rigid surfaces favour stress fibre formation in single cells, whereas elastic surfaces lead to a more diffuse cytoskeletal structure towards a random distribution of actin filaments. Takai et al. (2005) confirmed this for

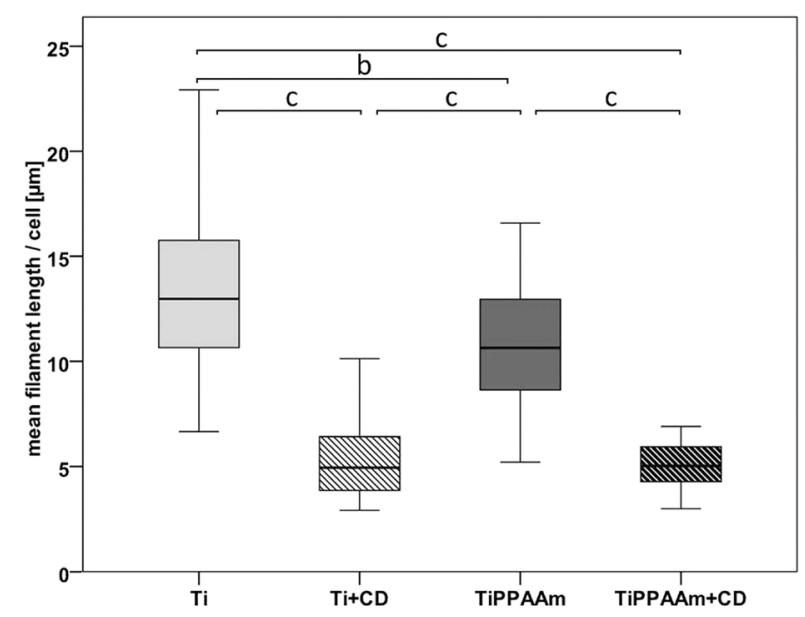

Fig. 7. Mean length of actin filaments in MG-63 cells on PPAAm-modified Ti after treatment with CD for $24 \mathrm{~h}$ (FilaQuant analysis of confocal microscopic images, $n=3$ independent experiments with 10 cells/specimen, one-way ANOVA, ${ }^{\mathrm{b}} p<0.01,{ }^{\mathrm{c}} p<0.001$ ).

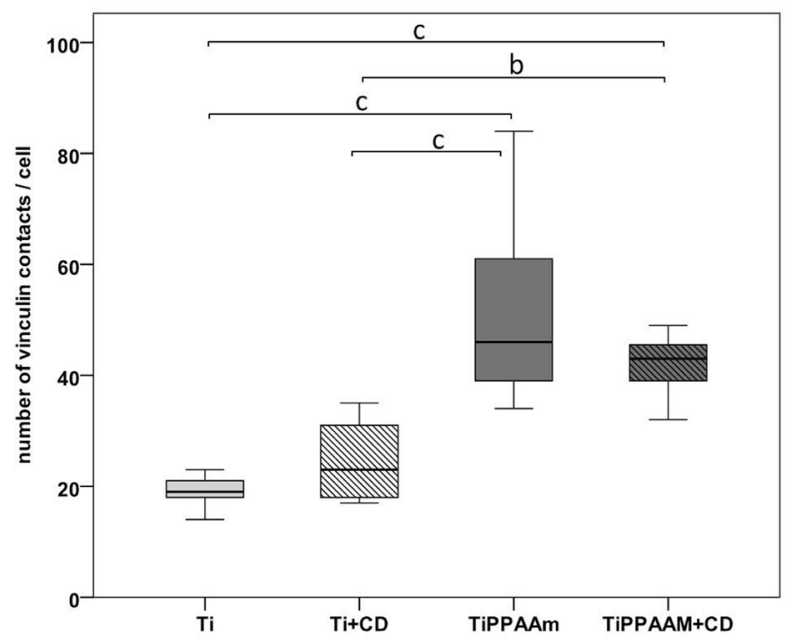

Fig. 8. Number of vinculin contacts in MG-63 cells on PPAAm-modified Ti after treatment with CD for $24 \mathrm{~h}$. (Analysis of confocal microscopic images with LSM software, $n=10$ cells/specimen, one-way ANOVA, $\left.{ }^{\mathrm{b}} p<0.01,{ }^{\mathrm{c}} p<0.001\right)$.

osteoblasts in vitro. Additional support comes from an experimental study done by Lanniel et al. (2011) for their ppAAm nanofilms on hydrogen silsesquioxane, showing a decrease of Young's modulus at increasing ppAAm film thickness parallel to an overall decrease in stiffness values. As the authors deduced from AFM nanoindentation measurements, the underlying substrate's stiffness has to be taken into account, as was demonstrated for $30 \mathrm{~nm}$ ppAAm layer thickness. Our deposited PPAAm nanolayer reaches a thickness of about $50 \mathrm{~nm}$ (Rebl et al., 2012). Interestingly, CD-treated cells on TiPPAAm (Fig. 4) formed distinct actin bundles, which argues for an indirect action of PPAAm related to its chemical characteristics. The cell-attractive effect of PPAAm was originally attributed to the primary amino groups of the polymer as an effect of their positive 

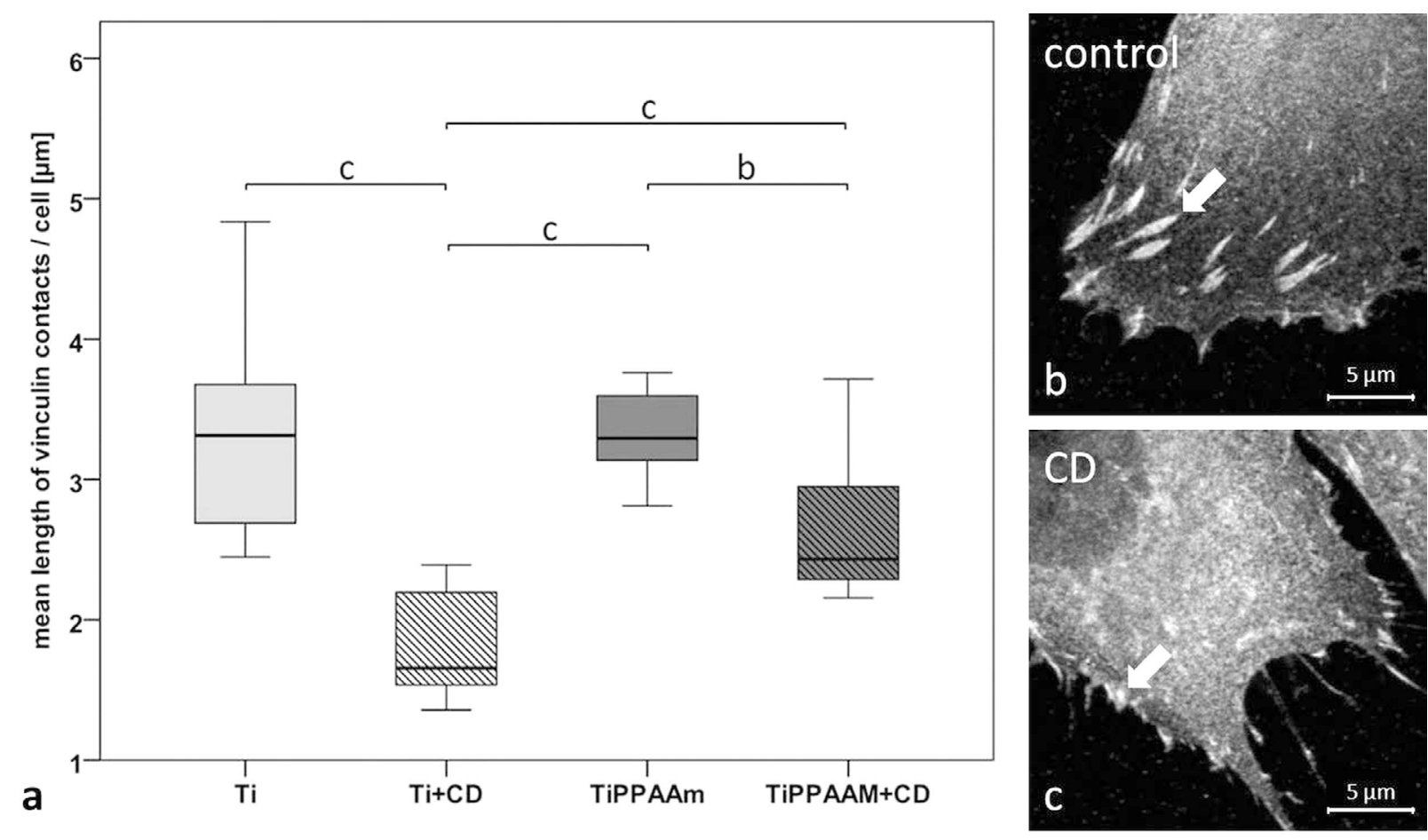

Fig. 9. Mean length (a) and phenotype of vinculin contacts in untreated (b) and CD-treated MG-63 osteoblasts (c) indicating clearly the loss in contact length due to CD treatment (LSM 410, bar $=5 \mu \mathrm{m}$ ). Arrows in (b) and (c) indicate the different size of vinculin contacts. Note that CD-induced shortening of vinculin contacts is counteracted by the supporting influence of the plasma polymer. (LSM $410, n=10$ cells/specimen, Mann-Whitney U-test, ${ }^{\mathrm{b}} p<0.01$, $\left.{ }^{\mathrm{c}} p<0.001\right)$.

surface charge (Finke et al., 2007). As amino groups of the monomer allylamine are partially changed during the plasma polymerisation into amide, imine or nitrile groups, it is now assumed that further nitrogen-containing functional groups, such as acid amides or imides, are also of relevance for initial cell functions (Finke et al., 2011a). Moreover, the hypothesis has been raised that a positive surface charge promotes initial cell adhesion and the spreading of osteoblasts, which produce a negatively charged pericellular hyaluronan matrix (Nebe and Luethen; 2008; Finke et al., 2007).

Accordingly, we analysed the formation of vinculin as a component of focal adhesion contacts after $24 \mathrm{~h}$ by assessing number and length. The organisation of vinculin, a fundamental adapter protein for integrins in focal adhesions (Diener et al., 2005; Humphries et al., 2007), shows parallels to the spreading results. Interestingly, mean length of vinculin contacts and cell area demonstrate the same trend. The number of vinculin contacts could therefore be rather a function of the expanded cell area. The mean length of vinculin was significantly reduced due to $\mathrm{CD}$ as it could be observed in the space flight study of Nabavi et al. (2011), where the exposure of osteoblasts to microgravity resulted also in smaller focal adhesions. The slight trend (non-significant) to increased contact numbers in the presence of $\mathrm{CD}$ on bare Ti could be interpreted as the cell's attempt to compensate for the lower cell area and, possibly, less intensive focal adhesions due to disturbed actin filaments.
Regarding the number, there are remarkable differences between actin and vinculin. As inhibition of actin polymerisation by $\mathrm{CD}$ resulted in numerous short actin aggregates, the trend to an increased filament number in CD-treated cells on Ti reflects this CD mechanism of action. PPAAm counteracts this CD effect as shown by reorganised actin filaments.

The fact that PPAAm boosted the number of vinculin contacts could reflect a higher bioactivity compared to $\mathrm{Ti}$, possibly arising from intramolecular and intermolecular interactions of the cationic polyelectrolyte in solution (Lee and Gardella, 2002). Here it is to be emphasised that, though some characteristics of PPAAm are described, knowledge about this polymer is still very limited and detailed physicochemical events related to the biological response to the polymer surface remain obscure. Comprehensive analysis of physicochemical material properties in physiological environments including high throughput assays would enable better correlation with cellular behaviour, but this requires great effort, as literature reflects the complexity of the interactions of biomaterials (Lee and Gardella, 2002). Exemplary, high-throughput material screening combined with high-throughput surface characterisation of 496 different acrylate polymers synthesised in a microarray format as carried out by Yang et al. (2010) in vitro revealed a strong relationship between the Time-of-Flight Secondary Ion Mass Spectrometry (ToF SIMS) spectra of bare polymers and human embryonic body stem cell adhesion, but no 
relationship between cell adhesion and wettability, surface roughness, elemental or functional surface composition.

Taking the unaltered level of the number and length of actin filaments for Ti and TiPPAAm into account, these results indicate that the enhancement of cell area elicited by PPAAm is carried out by cells without a distinct increase in the number or length of actin filaments. This assumption can be affirmed by in vitro data from (Matschegewski et al., 2010). Herein, the authors describe the behaviour of MG-63 osteoblasts on defined micropillar-structured surfaces, where cell orientation and spreading occurred despite the complete lack of organised actin fibres, but cells showed short filamentous actin solely on top of the pillars similar to what we see in the presence of CD. Interestingly, the actin cytoskeleton does not seem to contribute to the cell's spatial arrangement on a given surface topography, e.g. grooves and pillars. Originally it was assumed that spatial cellular orientation on material surfaces is performed by actin filaments, as it could be deduced from experimental evidence from Lüthen et al. (2005) showing the alignment of human osteoblasts along grooves on rough Ti surfaces; this is paralleled by directed formation of actin cytoskeleton. Thus, we hypothesise that on plasma-chemically modified Ti using PPAAm, cellular spreading proceeds without active participation of actin filaments.

A multitude of synthetic materials for permanent implants are available for modern orthopaedics, but these are not suitable for the specific requirements of systemic diseased bone. Referring to the motivation for this work, we can summarise that we were able to establish a cell culture model for a compromised cytoskeletal architecture of osteoblasts. Further, by using this in vitro model we could demonstrate that plasma polymer deposition on titanium improved the cell adhesion of physiologically restricted osteoblasts and their intracellular cytoskeletal structure. To our knowledge, this study is the first attempt aimed specifically to support impaired osteoblast adhesion by modification of the implant surface using low-pressure plasma technology. Thus, specific implant surface design could be beneficial for bone tissue regeneration at the bone-implant interface in the orthopaedic treatment of bone defects in patients with pathologically altered or weakened bone tissue.

\section{Conclusions}

Amino functionalisation of Ti surfaces by plasma polymerised allylamine deposition is beneficial for the adhesion and spreading capacity of osteoblastic cells with impaired cytoskeleton - artificially induced by cytochalasin D - providing a potential application for biovitalising specific implants for morbid bone tissues.

\section{Acknowledgements}

The author FK is grateful to the European Union and to the State Ministry of Economic Affairs, Employment and Tourism of Mecklenburg-Vorpommern in Germany for financial support within the joint project Tissue Regeneration (GEREMA) (EFRE: V220-630-08TFMV-F-009, ESV: V220-630-08-TFMV-S-009). We acknowledge the financial support of CM and FK by the DFG Research Training Group welisa (GRK 1505/1). $\mathrm{BF}$ and HR were financially supported by the project Campus Plasma-Med (BMBF, 13N9779 and 13N11188/ INP, 13N9775 and 13N11183/Cell Biol.). We acknowledge the excellent technical help of Janine Wetzel (BMBF, 13 N11183) and the valuable scientific input of Dr. Ulrike Bulnheim. We wish to confirm that there are no known conflicts of interest associated with this publication and there has been no significant financial support for this work that could have influenced its outcome.

\section{References}

Abbas A, Vercaigne-Marko D, Supiot P, Bocquet B, Vivien C, Guillochon D (2009) Covalent attachment of trypsin on plasma polymerized allylamine. Colloids Surf B 73: 315-324.

Beil FT, Seitz S, Priemel M, Barvencik F, von Domarus C, Rueger JM, Amling M, Pogoda P (2008) Pathophysiology and pathomorphology of osteoporosis. Eur J Trauma Emerg Surg 34: 527-534.

Birkholz H (2011a) Extracting the ridge set as a graph for quantification of actin filament images obtained by confocal laser scanning microscopy. Proceedings of the Society of Photo-Optical Instrumentation Engineers (SPIE), Tenth International Conference on Quality Control by Artificial Vision, St. Etienne, France, doi: 10.1117/12.895269.

Birkholz H (2011b) A unifying approach to isotropic and anisotropic total variation denoising models. J Comput Appl Math 235: 2502-2514.

Brakebusch C, Fässler R (2003) The integrin-actin connection, an eternal love affair. EMBO J 22: 2324-2333.

Bray D (1992) Actin filaments: structure and assembly. In: Bray D (ed) Cell Movement, Garland Publishing, New York, pp 75-92.

Clover J, Gowen M (1994) Are MG-63 and HOS TE85 human osteosarcoma cell lines representative models of the osteoblastic phenotype? Bone 15: 585-591.

Clover J, Dodds RA, Gowen M (1992) Integrin subunit expression by human osteoblasts and osteoclasts in situ and in culture. J Cell Sci 103: 267-271.

Corrado A, Cantatore FP, Grano M, Colucci S (2005) Neridronate and human osteoblasts in normal, osteoporotic and osteoarthritic subjects. Clin Rheumatol 24: 527-534.

Czekanska EM, Stoddart MJ, Richards RG, Hayes JS (2012) In search of an osteoblast cell model for in vitro research. Eur Cell Mater 24: 1-17.

Dequeker J, Mohan S, Finkelman RD, Aerssens J, Baylink DJ (1993) Generalized osteoarthritis associated with increased insulin-like growth factor types I and II and transforming growth factor beta in cortical bone from the iliac crest. Possible mechanism of increased bone density and protection against osteoporosis. Arthritis Rheum 36: 1702-1708. 
Diener A, Nebe B, Lüthen F, Becker P, Beck U, Neumann HG, Rychly J (2005) Control of focal adhesion dynamics by material surface characteristics. Biomaterials 26: 383-392.

El Miedany YM, Mehanna AN, El Baddini MA (2000) Altered bone mineral metabolism in patients with osteoarthritis. Joint Bone Spine 67: 521-527.

Ezzell RM, Goldmann WH, Wang N, Parashurama N, Ingber DE (1997) Vinculin promotes cell spreading by mechanically coupling integrins to the cytoskeleton. Exp Cell Res 231: 14-26.

Finke B, Lüthen F, Schröder K, Müller PD, Bergemann C, Frant M, Ohl A, Nebe BJ (2007) The effect of positively charged plasma polymerization on initial osteoblastic focal adhesion on titanium surfaces. Biomaterials 28: 4521-4534.

Finke B, Hempel F, Testrich H, Artemenko A, Rebl H, Kylian O, Meichsner J, Biederman H, Nebe B, Weltmann KD, Schröder K (2011a) Plasma processes for celladhesive titanium surfaces based on nitrogen-containing coatings. Surf Coat Tech 205: S520-S524.

Finke B, Rebl H, Schäfer K, Hempel F, Nebe JB, Weltmann K-D, Schröder K (2011b) Analysis of the aging behaviour of plasma polymer-coated titanium surfaces and correlation with the response of osteoblastic cells. Proceedings of the International Plasma Chemistry Society (IPCS), Philadelphia, USA, http://www.ispc-conference. org/ispcproc/ispc20/299.pdf.

Finke B, Rebl H, Hempel F, Schafer J, Liefeith K, Weltmann KD, Nebe JB (2014) Aging of plasmapolymerized allylamine nanofilms and the maintenance of their cell adhesion capacity. Langmuir 30: 13914-13924.

Gabler C, Zietz C, Gohler R, Fritsche A, Lindner T, Haenle M, Finke B, Meichsner J, Lenz S, Frerich B, Lüthen F, Nebe JB, Bader R (2014) Evaluation of osseointegration of titanium alloyed implants modified by plasma polymerization. Int J Mol Sci 15: 2454-2464.

Gonzalez RC, Woods RE (2008) Digital Image Processing. Pearson Prentice Hall, Upper Saddle River, NJ.

Hagiwara A, Tanaka Y, Hikawa R, Morone N, Kusumi A, Kimura H, Kinoshita M (2011) Submembranous septins as relatively stable components of actin-based membrane skeleton. Cytoskeleton 68: 512-525.

Hamerli P, Weigel T, Groth T, Paul D (2003) Surface properties of and cell adhesion onto allylamine-plasmacoated polyethylenterephtalat membranes. Biomaterials 24: 3989-3999.

Hilal G, Martel-Pelletier J, Pelletier JP, Ranger P, Lajeunesse D (1998) Osteoblast-like cells from human subchondral osteoarthritic bone demonstrate an altered phenotype in vitro: possible role in subchondral bone sclerosis. Arthritis Rheum 41: 891-899.

Hoene A, Walschus U, Patrzyk M, Finke B, Lucke S, Nebe B, Schröder K, Ohl A, Schlosser M (2010) In vivo investigation of the inflammatory response against allylamine plasma polymer coated titanium implants in a rat model. Acta Biomater 6: 676-683.

Humphries JD, Wang P, Streuli C, Geiger B, Humphries MJ, Ballestrem C (2007) Vinculin controls focal adhesion formation by direct interactions with talin and actin. J Cell Biol 179: 1043-1057.
Intranuovo F, Howard D, White LJ, Johal RK, Ghaemmaghami AM, Favia P, Howdle SM, Shakesheff KM, Alexander MR (2011) Uniform cell colonization of porous 3-D scaffolds achieved using radial control of surface chemistry. Acta Biomater 7: 3336-3344.

Kartsogiannis V, Ng KW (2004) Cell lines and primary cell cultures in the study of bone cell biology. Mol Cell Endocrinol 228: 79-102.

Klein-Nulend J, Bacabac RG, Veldhuijzen JP, Van Loon JJ (2003) Microgravity and bone cell mechanosensitivity. Adv Space Res 32: 1551-1559.

Lajeunesse D, Frondoza C, Schoffield B, Sacktor B (1990) Osteocalcin secretion by the human osteosarcoma cell line MG-63. J Bone Miner Res 5: 915-922.

Lajeunesse D, Reboul P (2003) Subchondral bone in osteoarthritis: a biologic link with articular cartilage leading to abnormal remodeling. Curr Opin Rheumatol 15: 628-633.

Lanniel M, Lu BR, Chen YF, Allen S, Buttery L, Williams P, Huq E, Alexander M (2011) Patterning the mechanical properties of hydrogen silsesquioxane films using electron beam irradiation for application in mechano cell guidance. Thin Solid Films 519: 2003-2010.

Lee JW, Gardella JA Jr (2002) Surface perspectives in the biomedical applications of poly(alpha-hydroxy acid)s and their associated copolymers. Anal Bioanal Chem 373: 526-537.

Lüthen F, Lange R, Becker P, Rychly J, Beck U, Nebe JB (2005) The influence of surface roughness of titanium on beta1- and beta3-integrin adhesion and the organization of fibronectin in human osteoblastic cells. Biomaterials 26: 2423-2440.

Matschegewski C, Stählke S, Löffler R, Lange R, Chai F, Kern DP, Beck U, Nebe BJ (2010) Cell architecture-cell function dependencies on titanium arrays with regular geometry. Biomaterials 31: 5729-5740.

Matschegewski C, Stählke S, Birkholz H, Lange R, Beck U, Engel K, Nebe JB (2012) Automatic actin filament quantification of osteoblasts and their morphometric analysis on microtextured silicon-titanium arrays. Materials 5: 1176-1195.

May JA, Ratan H, Glenn JR, Losche W, Spangenberg P, Heptinstall S (1998) GPIIb-IIIa antagonists cause rapid disaggregation of platelets pre-treated with cytochalasin D. Evidence that the stability of platelet aggregates depends on normal cytoskeletal assembly. Platelets 9: 227-232.

Myers KA, Rattner JB, Shrive NG, Hart DA (2007) Osteoblast-like cells and fluid flow: cytoskeletondependent shear sensitivity. Biochem Biophys Res Commun 364: 214-219.

Nabavi N, Khandani A, Camirand A, Harrison RE (2011) Effects of microgravity on osteoclast bone resorption and osteoblast cytoskeletal organization and adhesion. Bone 49: 965-974.

Nebe JGB, Luethen F (2008) Integrin- and hyaluronanmediated cell adhesion on titanium - Hyaluronan-mediated adhesion. In: Breme JK, Kirkpatrick CJ, Thull R (eds) Metallic Biomaterial Interactions, Wiley-VCH, Weinheim, pp 179-182.

Nebe B, Finke B, Lüthen F, Bergemann C, Schröder K, Rychly J, Liefeith K, Ohl A (2007a) Improved initial 
osteoblast functions on amino-functionalized titanium surfaces. Biomol Eng 24: 447-454.

Nebe JB, Lüthen F, Lange R, Beck U (2007b) Interface interactions of osteoblasts with structured titanium and the correlation between physicochemical characteristics and cell biological parameters. Macromol Biosci 7: 567-578.

Nebe JB, Cornelsen M, Quade A, Weissmann V, Kunz F, Ofe S, Schröder K, Finke B, Seitz H, Bergemann C (2012) Osteoblast behavior in vitro in porous calcium phosphate composite scaffolds, surface activated with a cell adhesive plasma polymer layer. Mater Sci Forum 706-709: 566-571.

Nebe B, Finke B, Hippler R, Meichsner J, Podbielski A, Schlosser M, Bader R (2013) Physical plasma processes for surface functionalization of implants in orthopedic surgery. Hyg Med 38: 192-197.

Neve A, Corrado A, Cantatore FP (2011) Osteoblast physiology in normal and pathological conditions. Cell Tissue Res 343: 289-302.

Nileback E, Enochson L, Altgarde N, Schnabelrauch M, Lindahl A, Svedhem S, Kunze A (2014) Acoustic monitoring of changes in well-defined hyaluronan layers exposed to chondrocytes. Analyst 139: 5350-5353.

Parreno J, Buckley-Herd G, de-Hemptinne I, Hart DA (2008) Osteoblastic MG-63 cell differentiation, contraction, and mRNA expression in stress-relaxed 3D collagen I gels. Mol Cell Biochem 317: 21-32.

Perrini S, Natalicchio A, Laviola L, Cignarelli A, Melchiorre M, de Stefano F, Caccioppoli C, Leonardini A, Martemucci S, Belsanti G, Miccoli S, Ciampolillo A, Corrado A, Cantatore FP, Giorgino R, Giorgino F (2008) Abnormalities of insulin-like growth factor-I signaling and impaired cell proliferation in osteoblasts from subjects with osteoporosis. Endocrinology 149: 1302-1313.

Raisz LG, Prestwood KM (2000) Epidemiology and pathogenesis of osteoporosis. Clin Cornerstone 2: 1-10.

Ratner BD, Bryant SJ (2004) Biomaterials: where we have been and where we are going. Annu Rev Biomed Eng 6: 41-75.

Rebl H, Finke B, Schröder K, Nebe JB (2010) Timedependent metabolic activity and adhesion of human osteoblast-like cells on sensor chips with a plasma polymer nanolayer. Int J Artif Organs 33: 738-748.

Rebl H, Finke B, Lange R, Weltmann KD, Nebe JB (2012) Impact of plasma chemistry versus titanium surface topography on osteoblast orientation. Acta Biomater 8: 3840-3851.

Ruoslahti E, Öbrink B (1996) Common principles in cell adhesion. Exp Cell Res 227: 1-11.

Schnabelrauch M, Wyrwa R, Rebl H, Bergemann C, Finke B, Schlosser M, Walschus U, Lucke S, Weltmann KD, Nebe JB (2014) Surface-coated polylactide fiber meshes as tissue engineering matrices with enhanced cell integration properties. Int J Polym Sci 2014: Article ID 439784.

Schröder K, Finke B, Ohl A, Lüthen F, Bergemann C, Nebe B, Rychly J, Walschus U, Schlosser M, Liefeith K, Neumann HG, Weltmann KD (2010) Capability of differently charged plasma polymer coatings for control of tissue interactions with titanium surfaces. J Adhes Sci Technol 24: 1191-1205.
Sun Y, Chen CS, Fu J (2012) Forcing stem cells to behave: a biophysical perspective of the cellular microenvironment. Annu Rev Biophys 41: 519-542.

Takai E, Costa KD, Shaheen A, Hung CT, Guo XE (2005) Osteoblast elastic modulus measured by atomic force microscopy is substrate dependent. Ann Biomed Eng 33: 963-971.

Vogler EA (2012) Protein adsorption in three dimensions. Biomaterials 33: 1201-1237.

Walcott S, Sun SX (2010) A mechanical model of actin stress fiber formation and substrate elasticity sensing in adherent cells. Proc Natl Acad Sci USA 107: 7757-7762.

Walsh NC, Reinwald S, Manning CA, Condon KW, Iwata K, Burr DB, Gravallese EM (2009) Osteoblast function is compromised at sites of focal bone erosion in inflammatory arthritis. J Bone Miner Res 24: 1572-1585.

Wittmann T, Waterman-Storer CM (2001) Cell motility: can Rho GTPases and microtubules point the way? J Cell Sci 114: 3795-3803.

Wyrwa R, Finke B, Rebl H, Mischner N, Quaas M, Schaefer J, Bergemann C, Nebe JB, Schröder K, Weltmann KD, Schnabelrauch M (2011) Design of plasma surfaceactivated, electrospun polylactide non-wovens with improved cell acceptance. Adv Eng Mater 13: B165-B171.

Yang J, Mei Y, Hook AL, Taylor M, Urquhart AJ, Bogatyrev SR, Langer R, Anderson DG, Davies MC, Alexander MR (2010) Polymer surface functionalities that control human embryoid body cell adhesion revealed by high throughput surface characterization of combinatorial material microarrays. Biomaterials 31: 8827-8838.

Yang Z, Tu Q, Wang J, Lei X, He T, Sun H, Huang N (2011) Bioactive plasma-polymerized bipolar films for enhanced endothelial cell mobility. Macromol Biosci 11: 797-805.

Yang Z, Tu Q, Maitz MF, Zhou S, Wang J, Huang N (2012) Direct thrombin inhibitor-bivalirudin functionalized plasma polymerized allylamine coating for improved biocompatibility of vascular devices. Biomaterials 33: 7959-7971.

Yeung T, Georges PC, Flanagan LA, Marg B, Ortiz M, Funaki M, Zahir N, Ming W, Weaver V, Janmey PA (2005) Effects of substrate stiffness on cell morphology, cytoskeletal structure, and adhesion. Cell Motil Cytoskeleton 60: 24-34.

\section{Discussion with Reviewers}

Reviewer I: Do you really think that a cytochalasin D-treated osteoblast model is a perfect model for osteoporotic osteoblasts?

Authors: We do not consider our model to be a perfect model for osteoporotic osteoblasts, but the chosen setup restricts osteoblastic cells in their adhesion processes. Parallel to the shorter actin filaments there are impaired adhesion contacts to be observed as indicated by altered vinculin formation. We did not want to focus on osteoporosis itself, but rather, in view of the socioeconomic dimension of this prominent bone disease, wanted to illustrate the background motivation of our experimental approach. To make this clearer we phrased 
the introduction in the way that we focused more generally on osteoblasts with impaired cell-functions and in critical conditions.

Reviewer III: I would refocus the paper with less insistence on cytochalasin as an in vitro model of osteoporosis, as in the absence of a stronger case this appears quite unconvincing.

Authors: Cytochalasin D was chosen as a tool to restrict cell functions related to the actin cytoskeleton as a major structural adhesion component. Therefore, the subsequent impairment of cellular adhesion behaviour provided a suitable approach to test the convincing adhesionsupporting potential of the plasma polymer layer PPAAm on titanium surfaces. As we mentioned in the introduction section, this model was set up as an approach to support cell adhesion of cells in pathological preconditions, and not necessarily of osteoporosis itself. 